\title{
The Gender and Geography of Citizenship in Mexico-U.S. Transnational Spaces
}

\author{
Luin Goldring
}

This paper proposes an approach for analyzing the gender and geography of citizenship practices in transnational social spaces in order to contribute to theorizing on state-transmigrant relations and citizenship. Drawing on feminist scholarship on citizenship, I conceptualize citizenship as including formal rights and substantive citizenship practices that are exercised in relation to different levels of political authority, and in different geographic sites within transnational spaces. The approach is used to examine dynamics between Mexican state policies and programs and transmigrant organizations in Los Angeles. Using data from research on migration between Zacatecas and California, I argue that men find a privileged arena of action in transmigrant organizations and Mexican state-mediated transnational social spaces, which become spaces for practicing forms of citizenship that enhance their social and gender status. Women are excluded from active citizenship in this arena, but often practice substantive social citizenship in the United States.

Key Words: Citizenship, Gender, Mexico, Transnational, Immigrants, Latinos

\section{INTRODUCTION}

The setting is a large meeting room at a convention center outside of Los Angeles. The event is the 1997 annual Miss Zacatecas contest 
and dance held in November by the Federación de Clubes Zacatecanos del Sur de Californin (Federation of Zacatecan Clubs of Southern California), an umbrella organization that represents over forty hometown clubs from the Mexican province of Zacatecas. ${ }^{1}$ The young women vying for the title are judged by a panel of notables, including two visiting researchers. This is the last of three competitions in which the candidates display their talents, including a speech demonstrating what they learned during their summer trip to Zacatecas-a tour sponsored in part by the provincial government. Most of the contestants were born in the U.S.; many attend university or junior college. The show is interspersed with the music of two bands and the patter of the M.C., who makes sure that the \$50.00-dollar-a-plate guests are entertained. In addition to the many tables filled with club leaders and members, and the judges' table, there is a large raised table for the guests of honor. This year, as in previous years, the governor of Zacatecas occupies the central seat. The governor crowns the winner and speaks warmly about the strong ties between Zacatecanos in the United States and their relatives back home. His speech praises clubs for their contributions toward community projects, and fills the audience in on some of his achievements as governor. The table of honor includes the president and vice-president of the Federation, their wives, the governor's liaison for migrant affairs, and this year, two Latino politicians. The audience also includes about a dozen mayors from Zacatecas.

The Miss Zacatecas contest and the events surrounding it, including the competitions for hometown club queens that lead up to it and the summer tour in Zacatecas, reflect participants' continued involvement with their place and country of origin and their engagement with Mexican political authorities. Club members spoke of the contest as a vehicle for educating "the youth" about their cultural heritage and reinforcing their pride in being Zacatecan and Mexican. They also stressed the importance of this and related events as fundraisers for club-sponsored community projects in their home towns. The projects were carried out through the " 2 for 1 " government matching funds program, which added two dollars to each dollar raised by the clubs. ${ }^{2}$ Carrying out these projects was the main reason for involvement in the clubs and the Federation cited by the club leaders and members with whom I spoke. They wanted to do something for their place of origin-and matching funds were distributed to clubs affiliated with the Federation. 
During the course of my research on relations between the Mexican state and transmigrants, the Miss Zacatecas contest was one of the contexts in which women's participation in hometown clubs or umbrella organizations was most prominent. Women were also visible in related activities. For example, they joined the summer tour of Zacatecas as chaperones, organized the rehearsals to set up the choreography for the contests, and participated in fundraising events in a number of ways-from preparing food to sell, to telling their friends and neighbors, to going to the events of other clubs as part of reciprocal exchanges.

However, women were virtually absent from positions of power in the Zacatecas Federation. There were no women on the mesa directiva (executive committee). One club had a woman president, and a few had women secretaries or treasurers, but only two or three women came to meetings on a regular basis. These were older women with grown children who came with their husbands. In Zacatecas, women were not involved on the government side of negotiations over the projects financed by the " 2 for 1 " program, except for one case in which a woman responsible for the social affairs portfolio in one municipality was also assigned responsibility over the " 2 for 1." Club representatives in Mexico were all men, although in a couple of cases, meetings to discuss " 2 for 1 " projects were attended by families, including women.

In the case of the Zacatecas Federation's activities (and most of the transmigrant group activities I was able to observe or talked to people about), women's participation was usually limited to "traditional" roles as (1) icons of femininity and bearers of Zacatecan culture and identity, as in the case of the Miss Zacatecas contest; (2) displays of male partner's status, e.g. as well-dressed wives of (successful) men during dances and other public events; (3) mothers, nurturers, cooks, and mature bearers and safekeepers of Zacatecan culture, for example as food-preparers at fundraisers, chaperones during the Miss Zacatecas tour, or coordinators of parts of the contest; and (4) in the case of women in Zacatecas, together with other members of the home communities (especially the elderly, poor, and sick), as beneficiaries of hometown club projects-as people in need of charity and/or protection.

These roles are associated with constructions of femininity, masculinity, sexuality, and gender relations that cast men as active and prominent in the "public" realm of politics and women in supporting, passive, roles. Whether or not these gender roles and relations 
hold in the everyday lives of these women and men, they are reinforced as ideals through events like the Miss Zacatecas contest, and they are mobilized successfully to raise funds for community projects. More importantly, they help to institutionalize and normalize constructions of gender that leave women out of positions of power in hometown organizations. Because these organizations are an important arena of interaction between the Mexican state and Mexicans in the United States, the ways in which participation in them is gendered has important implications for the gendering of citizenship in transnational social spaces.

This paper examines the uneven exercise of citizenship in MexicoU.S. transnational social space, using gender and, to a lesser extent, geography as key analytical constructs. It responds to the call for more careful attention to gender in analyses of transnationalism (cf. Hondagneu-Sotelo and Avila 1997; Mahler 1996, 1998, 1999; Pessar 1999a). Building on research on gender in Mexico-U.S. migration (e.g. Espinosa 1998; Goldring 1996a; Hondagneu-Sotelo 1994; Malkin 1998), I draw on feminist writings on citizenship (Stasiulis and Bakan 1997; Yuval-Davis 1997) to propose an approach for analyzing the gendering of transmigrant citizenship practices. Attention to gendered differences in the geography of citizenship, a phrase I use to highlight the possible disjuncture between the geographic location of citizens-in or away from their nation-state of citizenship-and the geographic orientation of their citizenship practices, complements the broader project of engendering theories of transnationalism.

The gendering of citizenship in transnational fields occurs in multiple ways, instigated by various actors and institutions. I argue that in addition to analyzing how gender works at the level of kin- and social networks, we also need to look at gender in the interaction between the state (at various levels) and transmigrant organizations. ${ }^{3}$ The analysis shows that transmigrant organizations and the Mexican state privilege constructions of masculinity and femininity that locate women in roles that support men's participation in hometown organizations. These constructions also normalize a nonpolitical and non-decision-making role for women in these organizations, leaving them to appear as adornments, nurturers, and perhaps passive recipients of state policy, but not as agents, claims-makers or active citizens. ${ }^{4}$ Faced with limited "benefits" in this relationship with Mexican political authorities and limited membership in the Mexican nation, most women have little incentive to become leaders 
in this arena. Instead, they are more likely to participate in issues and in locations that bear a more direct relationship to their identities as women, mothers, workers, and so forth, in their communities of U.S. settlement.

Data and Methods

The paper is based on initial work conducted in Mexico in the summer of 1995, eight months of fieldwork in Mexico and California during 1996-97, and follow-up work carried out less systematically in 1998 and $1999 . .^{5}$ The project was designed to study relations between the Mexican state and transmigrants, with a focus on hometown organizations in the Los Angeles area. In Mexico city, I interviewed staff in the Ministry of Foreign Affairs responsible for programs aimed at migrants, and representatives from the two main opposition parties. I also interviewed provincial government staff responsible for maintaining ties with migrants (for seven of the eight provinces that had active programs at the time), and visited projects and spoke with municipal staff in two provinces, Zacatecas and Jalisco. In Zacatecas, I also spoke with representatives of U.S.-based clubs. In the Los Angeles area, I interviewed leaders of umbrella or hometown organizations from twelve provinces, but focused on Zacatecas ${ }^{6}$ because of interesting developments taking place in relations between the Federation and the provincial government (Goldring 1998b, 1999a). I observed Zacatecas Federation meetings and attended fundraising events, and attended meetings of several other groups. At the Mexican consulate, I interviewed several staff members responsible for migrant outreach. The interviews were semi-structured, with a list of topics to be covered with different kinds of respondents. Those with club leaders were usually conducted in the respondent's home, which often allowed me to speak with other household members. I was able to see many people several times over the course of the research. This allowed me to establish rapport, build on previous information, and compare notes, both from different people and perspectives at any one time, and from individuals over time.

The next section reviews relevant work and develops a framework for analyzing the gendering of transmigrant-state relations. The third section illustrates the framework through a two-part discussion of Mexican migrant-led transnationalism and state-mediated transnationalism. In section four I discuss the implications for the geography of citizenship in Mexico-U.S. transnational spaces and 
take a closer look at the gendering of citizenship and state-transmigrant relations through a case study of the " 2 for 1 " program in Zacatecas. The final section offers some conclusions and ideas for further research.

\section{TOWARD A FRAMEWORK FOR ANALYZING THE GENDERING OF CITIZENSHIP AND TRANSMIGRANT-STATE RELATIONS}

Strands from literature in anthropology, sociology and political science dealing with various aspects of migration and immigration need to be brought together with work on citizenship in this effort to develop an approach for analyzing the gender and geography of citizenship practices in transnational social spaces, which is part of a broader attempt to contribute to theorizing on state-transmigrant relations. Each of these literatures offers important insights, but because of various gaps, they are best brought together and built upon.

The strong homeland orientation of Mexican hometown associations is not surprising. Portes and Rumbaut (1990: Ch. 4) note that first-generation immigrant voluntary associations tend to have this geographic focus to their activities. Basch, Glick Schiller, and Szanton-Blanc (1994) built their conceptualization of transmigrants and transnationalism around recognition of the strength and enduring quality of home ties and homeland oriented practices among some groups of first-generation immigrants. ${ }^{7}$ What is less commonly analyzed is the relationship between gender and various forms of organizing around hometown or homeland issues.

The extensive literature on Mexico-U.S. migration now includes important and varied work on gender (Espinosa 1998; Goldring 1996a; Hirsch 1999; Hondagneu-Sotelo 1994; Hondagneu-Sotelo and Avila 1997; Hondagneu-Sotelo and Messner 1994; Kanaiaupuni 1993; Malkin 1998; Mummert 1988; Rouse 1990). At the same time, the literature on transnationalism includes a growing body of work on the Mexican case and this state's responses to transnationalism (Goldring 1997, 1998b, 1999a, 1999c; Guarnizo 1998; Nagengast and Kearney 1990; Smith 1995, 1997, 1998, 2000). However, there is not much work in the intersection of these two areas. Analyses of gender relations and constructions of gender in the context of migration are usually conducted at the family or household level, and pay little attention to the role of state policies and actors in these processes. Similarly, studies of state responses to transnationalism have not used gender as a central conceptual category. 
Research on Mexico-U.S. migration and Mexican immigration in the United States in which gender is treated as a power relation and social process, not simply as a variable, provides a number of relevant findings. Chief among them is the conclusion that gender organizes migration in fundamental ways (Hondagneu-Sotelo 1994). Men and women who migrate experience the process differently: they generally go for different reasons and under different circumstances, and they may have differential access to social networks that provide distinct constraints and opportunities (Hondagneu-Sotelo 1994; Malkin 1998).

Researchers have also shown that women and men and tend to have divergent interests and plans regarding settlement in the United States: men tend to be more interested in returning to Mexico to live (Espinosa 1998; Goldring 1996a; Hondagneu-Sotelo 1994; Malkin 1998). ${ }^{8}$ Part of the explanation for this has to do with the ways in which gender intersects with class and racialization to limit the use of public space for Mexicans (and other immigrants) in the United States, especially men (Goldring 1996a; Hondagneu-Sotelo 1994; Malkin 1998; Rouse 1990). Another important reason for this lies in men experiencing a greater relative loss of status in the process of migration (Espinosa 1998; Goldring 1996a; Hondagneu-Sotelo 1994). Mexican immigrant men are usually in a subordinate position in the U.S. compared to their situation in Mexico, whether it is framed in terms of social status or patriarchal privilege-despite possible improvements in their standard of living. And they are certainly in a subordinate class and ethnoracial position vis-à-vis white men. Hondagneu-Sotelo and Messner argue that this structural marginalization is accompanied by the erosion of patriarchal privilege within the family. In addition to reduced spatial mobility, men lose authority in family decision-making processes and control over household labor (1994: 210; Goldring 1996a).

In contrast, women are less interested in returning to Mexico on a long-term basis because they tend to experience either a relative gain in status in the United States, or not as great a loss. Working outside the home for wages can improve women's ability to negotiate "patriarchal bargains"9 (Hondagneu-Sotelo and Messner 1994; Kandiyoti 1988). In contrast, returning to Mexico might involve the reassertion of stronger patriarchal authority and a return to the pre-migration gender division of labor in a setting where household work is often more taxing. It might also mean separation from children settled in the U.S. (Goldring 1996a). 
The literature on gender in the context of Mexico-U.S. migration thus suggests that interest in, and reasons for, maintaining transnational social spaces may differ significantly for men and women. At the level of social networks, kin-based transnationalism, and transnational communities, men and women are both active in constructing the cross-border social fields that constitute transnational spaces. However, women may be less interested in the long-term maintenance of transnational spaces, especially at the level of practices that are removed from immediate family ties, such as some of the activities associated with hometown organizations. While women generally continue to keep in touch with relatives and send money back home, they usually have a greater interest in settling in the U.S. than their male partners, particularly if most of their family members are there (Espinosa 1998; Goldring 1996a; Hondagneu-Sotelo 1994). Men's relatively greater loss of status helps us understand why they would be more interested in participating in hometown organizations than women, and why men might dominate this sphere of citizenship practice, but it is not a sufficient explanation. For that we need to look at family-level gender dynamics in relation to state policies and programs, and work on gender and immigrant political participation.

The U.S. state adopts at least two different stances, both of them gendered, in its relationship to Mexican immigrants. ${ }^{10}$ On one hand, it is a potential ally, particularly of women and children (Goldring 1996a; Hondagneu-Sotelo 1994). Women come into contact with state institutions through their children's education and because of health problems, domestic violence, or immigration issues (Goldring 1996a; Hondagneu-Sotelo 1994). This leads them to gain experience with government actors, who are usually more responsive than those in Mexico and who appear to limit patriarchal authority (Espinosa 1998; Hondagneu-Sotelo 1994; Malkin 1998). ${ }^{11}$ In contrast, Mexican men are more likely to experience the second face of the state: the state as a force of moral and legal regulation. Of course, in many areas, and especially along the border, gender operates somewhat differently: women and men are both targets of state discipline and enforcement. Overall, however, U.S. state actions contribute to men's interest in turning to Mexico to have their masculinity and social status valued appropriately, away from U.S. state regulation, while limiting-however unevenly-women's interest in doing so.

Since the early 1990s, the Mexican state has put in place a series of outreach programs aimed at Mexicans in the United States (Goldring 
1998a, 1998c, 1999a; Guarnizo 1998; Smith 1995, 1998). Analyses of this state-led transnationalism have pointed to the fundamental role played by state initiatives in maintaining transnational social spaces (Glick Schiller 1999; Goldring 1999a; Smith 1997, 1999). ${ }^{12}$ While not focusing on gender, authors have noted that state policies tend to privilege relatively elite male transmigrants (Goldring 1998a; Guarnizo 1998) and that transmigrant organizations are dominated by men (Goldring 1996a, 1999a, 1999c).

Research on Latino immigrant participation in homeland and U.S. politics complements these findings. ${ }^{13}$ It suggests that the homeland orientation of Mexican transmigrant organizations is fairly common among first-generation migrants (cf. Basch et al. 1994; Portes and Rumbaut 1990). However, this work generally does not address gender and political participation in general or in hometown organizations and homeland politics in particular. For this we can turn to subsequent scholarship that analyzes Latina and Latino conceptions of politics and political participation. Based on a study of Latinos in Boston, Hardy-Fanta (1993) argued that men and women had different definitions of, reasons for, and patterns of political participation. In Boston, Latino men were interested in positions, status, and elections. While women also worked on electoral politics, their definition of "what is politics" included personal consciousness raising and neighborhood and community issues and organizations. While her analysis focuses on political participation in Boston, Hardy-Fanta touches on the impact of home-country politics on U.S. participation (1993: 176-187). She suggests that the contrast between the structure of opportunities for political participation in the U.S. versus the homeland is an important variable shaping Latino participation in the U.S. (1993: 177-178). Hardy-Fanta does not extend her analysis to include the gender implications of the relationship between participation in home-country and U.S. politics. Jones-Correa (1998), in a study of Latinos in New York City, does. He argues that Latino men are more likely to be interested in dual-citizenship and active in homeland politics precisely because of inconsistency between their former social status, especially occupational status, and their current status in the United States. Activist Latinas, on the other hand, are more involved in U.S.-based political issues, largely because their status inconsistency is not as important.

Hardy-Fanta and Jones-Correa's studies are very suggestive regarding the gendering of citizenship practices in transnational spaces. However, both were carried out on the East Coast in settings 
where Mexicans were not a numerically important component of the Latino population, and, as a result, they do not figure prominently among their respondents. While Jones-Correa examines the question of dual-citizenship, both focus on political participation in the United States. Furthermore, Jones-Correa's emphasis on occupational status inconsistency raises questions about the relevance of this conclusion for groups who experience upward occupational mobility but a relative loss of other forms of social and gender status (e.g. many Mexicans) through processes such as racialization.

\section{THE GENDER AND GEOGRAPHY OF CITIZENSHIP PRACTICE IN TRANSNATIONAL CONTEXTS}

Because it involves the ideal of universal rights based on membership in a political community, citizenship is a useful point of entry for studying the gendering of transmigrant-state relations and transnational social spaces. Citizenship can include communitarian versions as well as attention to individual rights, and, with certain adaptations, can be applied to the range of practices that transmigrants, their organizations, and home states engage in with each other (Goldring 1998b). Most mainstream as well as feminist discussions of citizenship take Marshall's work as a point of departure. In a frequently cited passage, Marshall defined citizenship as "a status bestowed on those who are full members of a community. All who possess the status are equal with respect to the rights and duties with which the status is endowed" (1950: 28-29). Marshall pointed to the contradictory relationship between class-based stratification and universal citizenship, identified three dimensions of citizenship (civil, political, and social), and placed the development and expansion of citizenship in historical context by offering an evolutionary framework associated with the development of capitalism (Marshall 1950).

Contemporary theorists have built on Marshall's work and criticized it on numerous grounds (cf. Shafir 1998). The main problems of relevance to the present discussion are the need to address factors, in addition to class, that compromise the universal exercise of citizenship (e.g. gender, but the list also includes race, ethnicity, religion, and sexuality) and the importance of conceptualizing citizenship as taking place in transnational contexts. Feminist reformulations define citizenship as practice, rather than status (Lister 1997; Stasiulis and Bakan 1997; Yuval-Davis 1997). They argue that 
citizenship must be understood as a dynamic and multi-tiered practice (Stasiulis and Bakan 1997) that involves ongoing negotiations and struggles, not only with a central state, but with other instances and levels of political authority, ${ }^{14}$ from the local to the international. Feminist citizenship theorists also critique a widely held dichotomy between the public and the private, arguing that citizenship is practiced in both arenas (Prokhovnik 1998). Lister (1997: 33) draws attention to expanded notions of the "political" and "public good," recasting citizenship to include collective and "informal" politics, such as involvement in community organizations.

These reformulations of citizenship have several advantages. By paying-attention to local or subnational issues and politics, we can strengthen our analyses of state power and political authority at various levels (Nelson 1998; Goldring 1999a). By Including "informal" politics and engagement in community organizations we can analyze substantive as well as de jure citizenship practices (cf. Brubaker 1990), and expand citizenship to include more of what women actually do (Hardy-Fanta 1993; Pardo 1999) ${ }^{15}$ Considering the effects of international hierarchies on citizenship practices (Stasiulis and Bakan 1997) enhances the macro-transnational analytic strength of the approach. These moves help to focus on the actual citizenship practices of $\mathrm{im} /$ migrants $^{16}$ or transmigrants with specific state and non-state actors (Pessar 1999b).

However, one drawback of the feminist scholarship on citizenship is that it has been fairly nation-bound. The role of the state as the central institution involved in citizenship has needlessly limited discussions of membership, belonging, and rights to specific nationstates. Fortunately, people's relations to more than one state have begun to be taken up by academics working in this area (Stasiulis and Bakan 1997). Nevertheless, the problem has not been helped by the fact that the transnationalism literature has developed fairly separately from contemporary work on citizenship (exceptions include Castañeda 1998; Goldring 1998b; Ong 1993, 1999; Smith 1995).

In geography there is an emerging literature on the "spaces of citizenship" (Painter and Philo 1995) that can complement attention to the ways in which citizenship is gendered. This work draws attention to uneveness in the practice of citizenship within a national territory. From this perspective, uneven citizenship is shaped by dominant conceptions of who "belongs" and who does not, and where. An individual or group's ability to command financial and 
other resources also contributes to the uneven landscape of opportunities for (or limits on) citizenship. Conceptions of "who belongs" versus "others" can serve to exclude groups from various public spaces and places, excluding them or making them feel unwelcome. For example, people may be constructed as not belonging by virtue of being immigrants, non-white, homeless, gay or lesbian, women, too young, too old, poor, unemployed, uneducated, etc. Painter and Philo (1995) argue that informal designations of citizenship that compromise presence in public spaces also limit and make for uneven participation in civil society, and hence, citizenship. However, this literature is also nation-bound. Bringing a transnational optic to these insights allows us to talk about the geography or spatial dimensions of citizenship practices in transnational social spaces.

To sum up, I am advocating analyses of the gendering and geography (or location and orientation) of citizenship practices in specific transnational social spaces as a way to gain a better understanding of state-transmigrant relations, and, in particular, of how citizenship practices are gendered. Such analyses should include an examination of state-initiated policies and programs aimed at emigrants to see how these affect de jure and substantive citizenship practices, with particular attention to the construction of gender and membership. State policies in "receiving" countries deserve similar attention. A transmigrant-centered analysis might map out women's and men's de jure and substantive civil, political, and social citizenship $^{17}$ practices at different political levels and in different national contexts. Depending on the setting, the role(s) of non-state actors may be relevant, particularly in settings where non-state actors and institutions take on activities being off- or down-loaded by governments (cf. Pessar 1999b; Ong 1999).

\section{TRANSMIGRANT SUBSTANTIVE CITIZENSHIP AND MEXICAN STATE POLITIES TOWARD TRANSMIGRANTS}

Transnational social spaces or social formations are constituted through the practices of various actors and institutions with varying degrees of power, from "above" and from "below" (Basch, Glick Schiller, Szanton Blanc 1994; Guarnizo and Smith 1998). In the Mexican case, migrant-led transnational practices predate state responses, but both are currently crucial in generating and maintaining transnational spaces. 
Transmigrant-Jed Transnationalism

Mexican transmigrant-led transnationalism involves two important forms and levels of organization: kin- or family-based transnationalism, and broader transnational collectivities such as mutual aid societies and hometown organizations. The former is constituted by kin- and friendship networks, the latter by various kinds of organizations that often develop through kinship networks but generally have broader membership, specific goals, and a more formal organization. Kin-based transnationalism has its roots in the expansion (or fragmentation) of family, social, and community networks across the border through the processes of nation building and international migration. The Mexico-U.S. migration literature documents the key role of social networks in contributing to the cumulative causation, or self-feeding process, of migration (Massey et al. 1987).

Mexican transmigrants also have a long history of organizing to raise funds and carry out collective projects in their places of origin (Goldring 1992, 1996b, 1998a, 1999a, 1999b; Gonzalez Gutiérrez 1995; Moctezuma 1998; Smith 1995, 1997, 1998). Collective projects include church renovations and construction, cemetery improvements, transportation infrastructure (e.g. road construction and paving, bridges), sanitation infrastructure (potable water, drainage, sewage, washing areas, public bathrooms), electrification, school buildings, clinics, education and health equipment (e.g. text books, computers, ambulances), "urban" beautification (e.g. plazas, benches), recreational infrastructure (e.g. playing fields, rodeo rings), community halls, social welfare projects (e.g. old-age homes, allowances for the elderly and/or needy, Christmas presents for poor children), and, less frequently, productive infrastructure (e.g. irrigation) and small businesses (Goldring 1992, 1996b, 1998a, 1999c; cf. Levitt 1997; Smith $1995,1997,1998,1999) .{ }^{18}$ The groups may work with local religious or political authorities in Mexico, or on their own. Many hometown organizations have worked informally, coming together for particular projects, dissolving, and coming together again for another project, perhaps with new membership. Some of the larger and more continuous hometown and umbrella organizations have operated more formally, registering as non-profit organizations, and in some cases working with U.S.-based local politicians and community organizations (e.g., the Federation of Zacatecanos). Since 1993, largely as a result of Mexican state-led outreach programs, the number of hometown clubs and provincial-level umbrella organizations has 
grown, and many are registered with Mexican consulates in various U.S. cities. ${ }^{19}$

Transmigrant organizations represent a form of collective transnational practice, rather than individual or kin- or social network transnationalism (Goldring 1992, 1999a; Moctezuma 1998; cf. Portes et al. 1999). Most of the projects that are carried out are considered "public goods" that will benefit "the community," rather than profit-making ventures (Goldring 1996b, 1999b). As such, project-related activities are a form of substantive citizenship practice. In addition to embodying loyalty, identity, and sense of belonging associated with their place and country of origin, these organizations provide leaders with opportunities to develop status and political power, particularly if the groups are able to mobilize significant amounts of money for projects. Moreover, transmigrant organizations represent an increasingly institutionalized context for Mexico-oriented citizenship practice (Guarnizo 1998). Starting in the 1990s, hometown clubs and umbrella transmigrant organizations became one of the main targets of the Mexican state's efforts to court Mexicans abroad. These changes highlight the increasingly visible politicization of transmigrant organizations. Regardless of whether or not they frame themselves as "political," and relatively few do, these groups are becoming identified as political actors in several provincial and many municipal contexts (Goldring 1998b). ${ }^{20}$ Thus, in the case of Mexico-U.S. transnational spaces, transmigrant organizations are key interlocutors vis-à-vis Mexican state policies and political authorities at the municipal, provincial and federal levels, and they represent an important arena for transmigrant citizenship practice.

Mexican transmigrant organizations are largely male dominated. This is especially true with respect to Zacatecan organizations, the specific focus of my work. Women play important roles in some organizations from San Luis Potosi, Nayarit, and Guanajuato, but they are the exception. Given the overall pattern, these transmigrant organizations represent an arena of citizenship practice that helps to illustrate the gendering of state-transmigrant relations and transnational social spaces. While Zacatecan organizations do not represent all state-transmigrant organizations, their relationship to the Mexican state raises questions that may be relevant to other contexts.

State-mediated Transnationalism

A dramatic shift in Mexican government policy towards Mexicans residing outside the national territory began to take place in the late 
1980s. After years of ad-hoc government initiatives and consular protection going back as far as 1848 , the government began to reach out to Mexicans abroad in an effort to establish a new relationship with the diaspora (González Gutiérrez 1993, 1995). This was prompted by several related processes, including challenges to the PRI's hegemony and the support Cuahutémoc Cárdenas received during his "campaign" tours in the United States prior to the 1988 presidential elections, the government's desire to build a pro-NAFTA and pro-Mexico lobby among the Mexican origin population in the United States, and an interest in fostering closer economic as well as political ties with Mexicans and people of Mexican origin in the United States (Goldring 1999a; González Gutiérrez 1993; Guarnizo 1998; Ross 1998; Smith 1997, 1998). ${ }^{21}$

The Program for Mexican Communities Abroad (Programa para las Comunidades Mexicanas en el Exterior, or PCME, which was established in 1991, is one of the most concrete, and perhaps central, elements of the state's efforts to redefine its relationship with Mexicans abroad-which for all practical purposes means the United States. ${ }^{22}$ One of the PCME's main stated goals is to encourage Mexicans and people of Mexican origin to maintain social and cultural ties with Mexico, reinforcing national identity. The PCME is organized around a variety of thematic program areas aimed at different sectors of the Mexican and Mexican origin population in the United States.

The communities program within the PCME carries out the mandate of fostering closer ties between Mexicans in the United States and their localities of origin. Its designers astutely built on the existing structure of hometown clubs and their members' interest in carrying out projects to improve their hometowns. A matching funds program was established in 1993, modeled after an initiative that had recently begun in Zacatecas (Goldring 1998, 1999a; Smith 1997, 1998). It operated as a Federal program in six provinces until 1995, when it folded, in part because of the January economic crisis (Goldring 1999a). Zacatecas was the only province where the program continued in an institutionalized manner, through special agreements between provincial governors, the federal government, and the Federation of Zacatecan Clubs. The communities program also promotes the creation of new clubs and umbrella organizations throughout the United States. Most consulates now have a staffmember assigned to "communities" who organizes new groups, and brings existing ones into contact with the Consulate. 
Under the Zedillo administration, the PCME and related outreach programs aimed at Mexicans in the United States have continued. The government also engaged in an historic redefinition and expansion of membership in the Mexican nation that officially includes, or reincorporates, Mexicans abroad (Goldring 1997, 1998b, 1999a; Guarnizo 1998; Smith 1997, 1998). The Nación Mexicana initiative reiterated the goal of strengthening "the cultural ties and links with Mexican communities and people of Mexican ancestry living abroad" (PEF 1995: 15). Two strategies were identified for accomplishing this goal. The first involved the continuation of educational, cultural, and other exchange programs initiated under president Salinas, including the PCME, and thus was nothing new.

The second strategy was more innovative. It appeared to expand formal membership in the nation through constitutional changes that established the non-loss of Mexican nationality (not citizenship) for nationals who had obtained another citizenship, and permitting the recovery of Mexican nationality by the foreign-born children of Mexicans living abroad. However, these changes also reaffirmed a distinction between citizenship and nationality. The laws were approved in 1996 and went into effect in 1998 (Calderón 1998; Martínez Saldaña 1998b; Ross 1998). In 1996 a more significant modification was made to the electoral law, one allowing citizens to vote for president from outside their home districts (Calderón 1998). This established the possibility for Mexicans in the United States to vote in the 2000 Mexican presidential elections. However, on July 1, 1999, the PRI blocked any possibility of the vote when members organized a lack of a quorum in the Senate, just before the deadline for ruling on the issue in time for the 2000 election (Becerril 1999; Garza 1999; Reuters 1999). It is clear that for the ruling party, the nonloss of nationality was aimed at granting a largely symbolic form of membership in the nation, one that would affirm Mexican identity and nationalism and officially extend property rights, without granting formal political citizenship (Goldring 1999a; Ross 1998).

\section{IMPLICATIONS FOR THE GEOGRAPHY AND GENDER OF CITIZENSHIP IN TRANSNATIONAL SPACES}

The Geography of Citizenship Practice

Before Salinas' outreach programs and Zedillo's recent redefinition of the Mexican Nation, Mexicans living in the United States were 
not formally excluded from citizenship rights in Mexico, that is, they were not legally excluded from civil, political, or social rights, with the exception of ejidatarios, whose absence could lead to the loss of property rights. ${ }^{23}$ In practice, however, they were not acknowledged members of the nation, and the state did not encourage their citizenship practices-of any kind. The exercise of citizenship depended on resources and geographic location. If a person had the money, she or he could own property (civil rights). If Mexicans returned to Mexico with a valid election ID and in time to satisfy voting requirements, they could vote (political rights). As for social citizenship, one could argue, along with Ross (1998) that it was the unequal distribution and poor quality of social (as well as other citizenship) rights that drove migrants north in the first place. Transmigrants whose children remained in Mexico would receive benefits of social citizenship if their children were in public schools or sought public health benefits. In practice, this dimension would be extremely compromised, especially in rural areas with poorer public services.

Until recently, the Mexican state has offered Mexicans living abroad a limited form of citizenship. Although not formally excluded, in practice, their opportunities for exercizing voice and being represented were rendered virtually non-existent due to their absence from the national territory. In the United States, they could make limited claims for protection at Consulates, and were welcome to consider themselves Mexican and keep sending money to their relatives, or return to Mexico to live and vote. But they were not acknowledged members of the nation, and could not exercise political rights from abroad. Depending on various factors, including legal status, Mexicans were more likely to exercise some form of citizenship in the United States.

The citizenship rights in the United States of Mexican citizens and nationals varied considerably depending on legal status, but also on the social, historical, political, and economic contexts in which they lived. To take an extreme case, naturalized citizens were not immune to deportation during the mass deportations associated with the Depression, the end of WW-II and the Korean War (Operation Wetback), or during periods of xenophobia. Taking less extreme examples, we could say that prior to the 1996 Welfare Reform changes, undocumented Mexicans and permanent residents could exercise civil and social rights in the United States, for example by owning property, sending their children to public schools, and receiving public medical care. They might also be able to exercize some forms 
of political citizenship, e.g. by voting in school board elections or participating in community organizations, but not at the federal level. However, undocumented persons would be vulnerable to the insecurities associated with their lack of legal status, while permanent residents would have greater security (e.g., no fear of deportation). Naturalized citizens would, of course, have the most complete bundle of rights: de jure civil, political, and social rights in the United States, as well as de facto civil and perhaps some social rights in Mexico.

What kinds of citizenship practices did Mexicans in the United States engage in towards Mexico? Many continued to send money home in the form of remittances. Even if motivated by the need to support family members, remittances reaffirm claims of membership in families and communities. Some also worked on community projects in Mexico as a way of covering ground left vacant by a retreating state sector (Goldring 1992). Others took a more public and activist position, expressing their sense of membership by supporting or making demands on the government of the day (Ross 1998; Martínez Saldaña 1998a, 1998b). Clearly, Mexicans retained a keen interest in the affairs of their communities and country of birth, although this took diverse forms. Many continued to think of themselves as part of the nation, regardless of whether membership was legitimated by the state or local authorities.

The recent constitutional reforms affecting nationality should be seen as symbolic incorporation, as they do little to change the geography of citizenship practice in Mexico. The legal changes were supposed to restore civil citizenship rights, e.g. the right to own property in Mexico. But if we look at the practices of Mexicans in the United States, we see that many-especially those from agricultural backgrounds-had owned property in Mexico and continued to do so, whether they were explicitly allowed to or not (Massey et al. 1994; Ross 1998). The opportunity to exercise social rights was not altered by the laws, and political rights were clearly excluded.

However, the geographic arena where the Mexican state is promoting political citizenship is the United States. One of the less explicit but clear messages being conveyed by PCME and consular staff is the promotion of United States naturalization in order to defend one's rights in that territory (Guarnizo 1998; Martínez Saldaña 1998a; Interviews). With naturalization, the non-loss of nationality gains even greater symbolic currency. If one becomes a naturalized U.S. citizen, one can retain (or apply for) Mexican nationality. One can have it both ways: be loyal to Mexico, but strategic 
about one's rights and interests in the U.S. Although this may expand political citizenship in the United States, it does not improve political citizenship in Mexico, at least for now.

The approach to citizenship promoted by the Mexican state is one in which political rights are exercised in the United States, civil/ property rights can be exercised in either country-depending on resources, social rights are more likely to be exercised in the United States, and everyone remains patriotically loyal to Mexico. The Mexican state offers symbolic membership because the current law does not provide political citizenship to those living abroad. This is a form of membership based on the market, or market citizenship (Schild 1998), in that it offers limited de facto membership preferentially to those who send remittances, invest in Mexico, and work with the government's outreach programs. Transmigrants may be symbolically reincorporated and exercise substantive citizenship through these practices, but they are not full or equal members of the nation. Borrowing from Ong's (1999: 214-239) discussion of new zones of sovereignty, we can say that the recent constitutional changes represent a rezoning of the Mexican state's sovereignty so as to include Mexicans abroad. But just as there is graduated sovereignty (Ong 1999: 215) within Mexico, with unequal "rights, discipline, caring and security" (Ong 1999: 217) for different groups, there is also graduated sovereignty with respect to Mexicans in the United States. The next subsection addresses the graduation of sovereignty with respect to gender.

\section{The Gender of Citizenship}

In this section I focus on the " 2 for 1 " program and the Federation of Zacatecan Clubs to show how transmigrant citizenship and transmigrant-state relations are gendered. Through programs like the "2 for 1," transmigrant men broaden the social citizenship benefits and social standing of their places of origin. In so doing, they may also expand their substantive political citizenship (Goldring 1998b, 1999a). This male dominated process is structured both by the ways in which outreach programs work and the way transmigrant organizations are accustomed to operate.

In Mexico, public, formal, political citizenship remains a predominantly male arena despite the fact that, starting in the early 1980s, the panorama of women's formal and informal participation in politics began to change dramatically. The number of women elected to political office increased (Rodriguez 1998); women's participation 
became more visible in urban grassroots movements (Bennett 1998), NGOs (Tarrés 1998) and local opposition movements (Nelson 1998); and women have played a key role in the Zapatista movement (Stephen 1998). Despite such gains, significant constraints continue to prevent women from coming close to achieving gender parity in electoral politics (Camp 1998). At the municipal level, few women are elected as mayors, alderwomen, or municipal trustees (Massolo 1998). In 1998, only one out of the 56 municipalities in Zacatecas was governed by a woman. In the same year, other provinces with high rates of United States-bound migration had similarly low rates of women in municipal leadership positions. In Guanajuato 1 out of 46 municipalities were governed by women; for Michoacán and Jalisco the figures were 3 out of 113, and 2 out of 124, respectively. Again, in the same year, nine of the country's states had no women mayors. Veracruz, the state with the largest number of municipalities governed by women, had nine women mayors out of 207 municipalities (Massolo 1998: 201). It follows that the political culture that most transmigrants are familiar with in Mexico does not present many opportunities for, or models of, women's participation in formal politics. ${ }^{24}$

As indicated earlier, it appears that this aspect of political culture extends to transmigrant organizations in the United States. The Federation of Zacatecan Clubs of Southern California is one of the oldest, largest, and strongest umbrella organizations in the United States (Goldring 1997, 1998a, 1998b, 1999a; González Gutiérrez 1995; Zabin and Escala Rabadán 1998). It is also, as previously noted, a male-dominated organization. That is, substantive citizenship practice exercised through the organization is practically synonymous with male citizenship. This is a result of the interplay between the ways in which gender works through state policies and programs, such as the " 2 for 1 ," how gender relations structure participation in organizations like the Federation of Zacatecan clubs, and the relatively greater loss of status for Mexican men in the United States. This can be seen more clearly through a discussion of " 2 for 1 " projects and how they operate, what it takes to participate in Federation activities, and the benefits associated with participation.

Reproducing Male Privilege through the " 2 for 1 "

Plans for " 2 for 1 " projects develop in various ways. Some are one or a few people's pet projects, while others have broader backing and management. They may stem from requests from people in the 
locality in Mexico, or from the ideas of club members in the United States, or from discussions between the two. In any case, they often emerge as a result of discussions among men and women. However, after that, carrying out projects is men's business. Women participate in fundraising and attend many public functions, but they are rarely involved in project implementation. This both reflects and contributes to the dominance of men's citizenship practice in hometown organizations. How and why does this take place? One explanation lies in the organization of the Federation and how gender structures participation in organizations like the Federation. Another lies in the gendered quality of political culture and the networks of power that are mobilized and through which people navigate in order to get things done in Zacatecas.

\section{Gender, Organizational Structure and Participation, and Scaling Up}

Women participate in many hometown clubs, attend meetings, have a say in decisions, and also play more traditionally feminine roles in fundraising activities (preparing and selling food, etc.). However, when it comes to representing the club at Federation meetings, most delegates are men. The executive committee (mesa directiva) has been made up of men almost exclusively since the Federation was established, although there have been women secretaries (usually young unmarried women, accompanied by a relative). ${ }^{25}$ Three reasons for the absence of women in Federation leadership positions stand out. First, once a club participates in the process of scaling-up by joining an umbrella organization like the Federation, participating in club activities is no longer a question of families who know each other working together. Instead, citizenship practice shifts from this more familial and community arena to an explicitly public sphere of meetings, official events, and negotiations with Mexican political authorities and consular staff. While there is no Federation rule barring women, the common sense knowledge is that positions of power are for men. In meetings with consular staff, the governor, or mayors, men sit at the negotiation table, women sit in the audience or meet separately with the governor or mayors' wives.

Second, prevailing gender relations do not facilitate women's participation in this more public arena of citizenship practice. Women may support particular projects, but they will not be the ones pushing them through (see below). Women, particularly those with children, find it difficult to attend meetings-not necessarily because their husbands "wouldn't let them," but because everyone 
knows that the family comes first. Meetings are held in the evening, usually during the week, they run quite late, and involve a long drive for most participants. Women's attendance would imply neglecting their families. Men's active participation both depends upon and reproduces gender relations that involve women staying home to care for children. Only a couple of older women whose children were grown attended meetings on a regular basis during my fieldwork, and they did so with their husbands.

Third, women who try to promote a different agenda within the Federation are usually marginalized. The wife of one club leader told me how a number of years ago, she and a group of women had tried to form their own club, paid their Federation dues, and wanted to promote educational and cultural exchange projects. They attended meetings for nearly a year, but finally lost interest because they felt they were always ignored. There is also the case of "Rita," a young woman born in Zacatecas, who has lived in the United States most of her life. She has been involved in a number of Latino community organizations since her university student days, and decided to form a hometown club a couple of years ago (after I had completed most of my fieldwork). Rita attended Federation meetings as the president of her club, and was not afraid to speak her mind. However, her interventions were often met with disapproval. She was considered loud, opinionated, and "not familiar with the way things are done." Despite a great deal of frustration, she continued to participate, but expressed doubts about how long she would continue to try to engage with this organization.

\section{Gender and the Politics of Project Implementation}

A certain ambiguity or lack of transparency about the way projects were approved by the previous governor's staff ${ }^{26}$ meant that projects required negotiation at many stages in order to be initiated, approved, funded on time, and completed properly. In the 1996-98 period, a proposed project also had to receive approval at the municipal level as part of a recent national decentralization program (Goldring 1999a). While club leaders did not necessarily have to travel to Mexico to participate in the municipal meetings, they often engaged in lobbying with their mayor, relevant municipal staff, the governor, and the governor's liaison. If a problem occurred during a meeting that might threaten a project, local representatives would usually contact the club leaders, who would try to apply pressure through their networks to make sure the project got funded. If a 
club's leaders, club representatives in Mexico, or a municipal presidents wanted to negotiate better terms for any aspect of a project, they relied on male networks of power based on compadrazgo, student cohorts, and former jobs. Projects also required follow-up once approved. Money had to be disbursed at the right time. Prices for building materials changed, making it difficult to follow initial budgets. Someone had to make sure that public works staff at the municipal level followed-up, and that construction teams did a good job. A club leader might have to make several calls and perhaps some trips to Mexico to make sure that work was carried out to his satisfaction. In the process, he was likely to draw on various contacts to make sure things went well. Club representatives in Mexico did much of this follow-up work, but club leaders in California and club representatives in Mexico repeatedly told me that, in many cases, authorities in Mexico paid more attention to transmigrants, so transmigrant leaders had to be very involved.

\section{Gender and Incentives to Participation}

Women may approve of and benefit from projects carried out in their home communities, but they rarely engage in the citizenship practices associated with project implementation. Women encounter limits on their participation in leadership positions in umbrella organizations in the United States, and they would face similar difficulties trying to negotiate the labyrinths of power in Mexico. Men usually have an easier time mobilizing the amount of resources and time necessary to devote to such activities. What we see, as a result, is active substantive citizenship exercised by male transmigrants in relation to provincial, municipal, and in some cases, federal authorities in Mexico. This citizenship practice expands the social citizenship benefits of the communities where projects are carried out (Goldring 1998a, 1999a), which often contributes some degree of power or leverage in negotiations with Mexican authorities. It also provides transmigrant leaders with a space for performing gendered citizenship and a particular form of masculinity. Together, these reproduce male privilege in ways that are either not available in the United States for some men, or which complement relatively high status in the United States for others. In sum, the political culture that surrounds the organization of, and participation in, the Federation, together with the way " 2 for 1 " projects are carried out, are extremely gendered processes. They depend on male privilege and reproduce 
it. Women may decorate the Federation's annual magazine (FCZSC), but they do not occupy positions of power in the organization.

I am not suggesting that the state's outreach programs and the ways they are implemented at the subnational level are explicitly designed to perpetuate male privilege, but that they end up doing just that. They build on existing gender relations, ideologies, divisions of labor, and hierarchies, and facilitate the reproduction of a political culture dominated by gendered networks of power. While many hometown organizations existed before the state began to take a systematic interest in Mexicans abroad, state policies and programs have increased the number and strength of the organizations and contributed to their becoming political actors vis-à-vis the Mexican nation. The state plays a key role in the process of gendering citizenship in transnational spaces by promoting projects such as the " 2 for 1 ," encouraging mayors to meet with their "constituents" in the United States, and generally trying to bring transmigrants into the sphere of influence of Mexican political authorities. The willingness of provincial and municipal political authorities in Mexico to court and engage with transmigrants as part of their own political agendas expands the opportunities of transmigrant male leaders to overcome any marginalization they may experience in the United States (cf. Hondagneu-Sotelo and Messner 1994), and to exercise a form of citizenship that raises their social status, increases their social capital, and expands their social citizenship as well as that of their communities of origin. By building on existing forms of male-dominated organizations and not taking steps to alter women's patterns of participation, the state's efforts to reincorporate Mexicans offers men a version of citizenship, limited as it may be, that is largely unavailable to women. It is in this sense that Mexican state policies contribute to the gendering and geographic orientation of citizenship in transnational spaces.

\section{CONCLUSIONS AND IMPLICATIONS FOR THE GENDER, GEOGRAPHY, AND SUBSTANCE OF TRANSMIGRANT CITIZENSHIP}

Transnational social spaces or fields are not necessarily uniform with respect to the gender, location, and orientation of citizenship practices. Transmigrant men and women are likely to practice various dimensions of citizenship (e.g., social, political) in, and/or oriented toward, state institutions in different national contexts. My research, together with that of other scholars, points to a specific 
pattern in the gendering of citizenship in transnational social spaces: Men are likely to dominate homeland oriented citizenship practices. To the extent that masculine citizenship is priviledged in these spaces, states and transmigrant organizations are limiting the opportunities and incentives for women's participation. As a result, women's citizenship is more likely to be practiced in the host-country context.

This research supports the conclusion suggested by authors such as Hardy-Fanta (1993) and Jones-Correa (1998) that opportunity structures for exercizing citizenship for women and men may determine the gender and location of citizenship in transnational spaces. My research focused on hometown organizations and their relationship to the Mexican state. As such, it speaks to the gendering of citizenship in this transnational context and shows how Mexican state policies and the Zacatecan Federation privilege men's substantive citizenship. However, I did not conduct primary research on women's (or men's) definitions of politics or their participation in other arenas. There is ample room for further research on the gendering of transmigrant citizenship.

My research highlights two points that have broader theoretical relevance. First, it is important to conceptualize and analyze citizenship as a practice that potentially takes place in transnational contexts, involving more than one nation state. This requires attention to the geographic location and orientation of citizenship. Second, analyzing the gendering of state-transmigrant relations and citizenship practice requires an examination of the interaction between domestic gender relations and state policies and programs, particularly as they play out in the context of key arenas of transmigrant citizenship practice, such as hometown associations.

This research highlights the role of the Mexican state in contributing to the geographic fragmentation of transmigrant citizenship practices. The Mexican state is pushing Mexicans living in the United States to naturalize while retaining close affective ties to Mexico, in the hopes of perpetuating investment, remittances, and "international cooperation projects" such as the " 2 for 1 " matching funds program. This amounts to pushing transmigrants to orient their substantive or de facto social and civil citizenship rights toward Mexico, and their de jure political and social rights toward the United States.

Gendered differences in the exercise of citizenship in transnational spaces compound the geographic unevenness. Together, they reflect Mexican graduated sovereignty vis-à-vis transmigrants. The role of 
the state is crucial in these processes. State policies and programs, Mexican political culture, the structure and organization of the Federation of Zacatecan clubs, and gender ideologies as they play out at the domestic level come together in a way that promotes active male citizenship while relegating women's participation to traditional roles as cooks, mothers, or beauty queens. This contributes to women having little opportunity or incentive to exercise active substantive political citizenship through the Federation or in this transnational arena.

The literature on Mexican and other immigrant women in the United States shows that Mexican and other Latina women are far from passive or politically uninvolved. On the contrary, Mexican and other Latina women are, and have a history of being, active in a range of community organizations (Hardy-Fanta 1993; Pardo 1999), the environmental justice movement (Pardo 1999), non-traditional labor organizing (Hondagneu-Sotelo and Riegos 1997), and local politics (Hardy-Fanta 1993; Jones-Correa 1998). Without the combined attention to the gender and geography of citizenship in transnational contexts, one could miss important aspects of men's or women's citizenship practices. For example, focusing on transmigrant citizenship practices toward Mexico without looking at the United States could suggest that transmigrant women are not politically involved. Conversely, studying Mexican immigrant participation in environmental grassroots organizations might lead one to wonder where the men were.

This supports the conclusion that transmigrant/immigrant women who find their practice of citizenship blocked in home-statemediated transnational social spaces are more likely to engage in substantive citizenship oriented toward expanding social citizenship for their families in the United States. This tendency may be shaped by conformity to "traditional" gender norms, in that women's adherence to elements of patriarachal gender relations contributes to their focusing on issues related to children and family, such as schooling, health, the local environment, and labor. At the domestic level, their involvement may lead to tension as women's U.S.-oriented substantive citizenship and men's Mexico-oriented citizenship contribute to divergent long-term settlement plans. At a broader level, the gendering of citizenship in transnational spaces may contribute to differences in feelings of membership and belonging in the relevant nations, and thus to the gender of membership in the nation (cf. Yuval-Davis and Anthias 1989). 
The specific mechanisms that contribute to the gendering of citizenship in transnational spaces deserves further comparative research (e.g. Levitt 1999). My research has emphasized the interaction between gender relations, men's relatively greater loss of gender and social status through migration, and home-state policies and programs. However, comparative research on different transmigrant groups and sending states, and the ways their policies contribute to the gendering of transmigrant citizenship practices, can tell us more about the implications for women and men's citizenship practices in the United States and "at home." This, in turn, can improve our theorization of transnational social spaces, citizenship, and transmigrant women and men's participation in multiple settings.

\title{
NOTES
}

\author{
Luin Goldring \\ York University \\ CERLAC \\ 240B York Lanes \\ 4700 Keele St. \\ Toronto, Ontario M3J 1P3 \\ Canada \\ goldring@yorku.ca
}

LUIN GOLDRING is associate professor of sociology at York University in Toronto. She has recently begun a research project on the political involvement of Latinos in Toronto. In earlier research on Mexico-U.S. migration, she examined changes in statetransmigrant relations, citizenship, gender relations, and the construction of transnational communities. She has also conducted research on property rights reform and natural resource management in Mexico.

Acknowledgements: I am grateful to Sarah Mahler and Patricia Zavella for pointing me in this direction, to Patricia Pessar and Sarah Mahler for organizing the conference where this paper was presented, and to Sarah Mahler, Patricia Pessar, Nina GlickSchiller, Audrey Singer, Pierrette Hondagneu-Sotelo, Ludger Pries, Peter Vandergeest and three anonymous reviewers for valuable comments on earlier versions of this paper. Remaining problems are my responsibility. An earlier version of this paper will appear in a volume edited by Ludger Pries (2001).

1. Zacatecas is a province in north-central Mexico that has historically been one of the top four migrant "sending" states, along with Jalisco, Michoacán, and Guanajuato. In addition to sending a large number of workers to the United States, researchers estimate that in 1992 the state ranked highest in international migrants as a percent of the total population (9.9\%) (INEGI 1992, cited in Moctezuma 1998: 13). The provincial economy is heavily dependent on U.S. dollar remittances. 
Salazar Rodnguez (1996 16-23) estimated that in 1994, remittances sent through banks, telegraph wring, the postal system, and money exchange houses came to 241,000,000 US dollars Thus represented $1128 \%$ of the 1993 GDP (see INEGI 1996 369) The dollanzation of many village economies helps to mitigate the effects of unemployment, spatıally concentrated and limited industrial development, the declining mining industry, and relatively poor conditions for agnicultural and livestock production In 1990, CONAPO, the Mexican National Commission on Population, ranked Zacatecas the 8th poorest state in the country, after Chrapas, Oaxaca, Guerrero, Hıdalgo, Veracruz, Puebla, and San Lu1s Potosı (World Bank 1994 53) For background on migration from Zacatecas, see Mines (1981), Delgado Wise (1991), Salazar Rodnguez (1996), Moctezuma (1998), and Padilla (1998)

CONAPO estrmates that the current annual volume of remittances going from the US to Mexico is just under 8,000,000,000 dollars (Infosel 2000)

2 From 1993-1995, the " 2 for 1" operated at the federal level as part of the Programa para las Comunidades Mexicanas en el Extranjero (PCME, Program for Mexican Communities Abroad) The program operated in s1x provinces, but Zacatecas had the largest expenditures (Goldring 1999a) After ending at the federal level, the " 2 for 1 " continued to operate in Zacatecas A new " 4 for 1 " was negotiated with the current governor For additional background on the PCME and "2 for 1" program, see Smuth (1997, 1998, 1999), Guamuzo (1998), and Goldrung (1998a, 1999a, 1999b, 1999c)

3 Following Basch, Glick Schiller, and Szanton Blanc (1994) I use the term transmigrant to refer to migrants or immigrants who retain strong and active social, economic, cultural, and political thes to therr countries of origin The term does not ignore structural factors behind the process of migration, but emphasizes the agency involved in the creation and maintenance of social fields that span the sites in which transmigrants and their familes conduct their lives I use transmigrant organizations to describe a broad range of organizations estabished by transmigrants, with the basis of membershup resting on a shared identity rooted in the place or region of ongin Some of these organizations have a strong homeland orsentation to their activities, but this does not necessarly preclude US -based activities

4 More recently, a young woman doing an M A in the Los Angeles area has become active in the Zacatecan Federahon as a Club president However, she is an exception to the overall pattern, and has faced considerable resistance

5 The research was supported through a post doctoral fellowshup from the Social Science Research Councl I am also grateful to the North American Integration and Development Center at UCLA, where I was affiliated

6 Umbrella organizations existed for some, but not all, provinces While there is no consistent relationship between the estimated number of people from a given province and the number of hometown clubs from that political unit, Zacatecas and Jalısco have consistently had the largest number of clubs (45 and 30, respectively, in 1996) and are among the top "sending" states (see discussions in Goldring 1999a, Gonzalez Gutierrez 1995, Zabin and Escala 1998)

7 An analytical distınction can be drawn between immigrant and transmigrant organzations, although the difference is more of degree than of kınd Immigrant organzations may include advocacy groups (for immugrants, not necessanly run by them) and organizations whose first-generation membership is based on shared ethric, national, or regional origin Most of thetr activities focus on the host country and its institutions Transmigrant organizations are established by 
first generation immigrants with strong home-land thes, their activities are oniented toward their country of ongin and its institutions In practice, transmigrant organizations may become immigrant organizations as transmigrants become mcreasingly engaged and familiar with the host-country state and culture

8 See Grasmuck and Pessar (1991) for similar discussions with respect to DominIcan-U S migration, and Mahler (1996) on El Salvador

9 This refers to women's opportunities to negotiate the gender division of labor and gender relations within the constraints of patriarchy Gains, however small or relative, may be very important to women even if they do not fundamentally alter the overall structure

10 This paper focuses on Mexican transmigrant relations with the Mexican state, not that of the Unted States Treatment of the latter is limited, although ideally, as suggested further on, it should receive more attention

11 Passage of anti-1mmigrant legislation such as Proposition 187 in California and Federal legislation changing access to public benefits for immigrants ( $\mathrm{e} g$, the Personal Responsibility and Work Opportunuty Reconcliation Act of 1996) certainly challenge a conception of the US state as an ally In Californa, Proposition 187 was closely identified with Governor Pete Wilson and the Republican party, and not all facets of political authority in the US

12 A note on terminology is in order I follow Basch, Glick Schiller, and Szanton Blanc's (1994) by now well known definition of transmigrants (cf Glick Schiller 1999) Use of the following terms is conditioned by my fieldwork I find Rouse's (1991) use of transnational migrant crcuits useful, but use transnational communities to describe transnational spaces linked to particular localities or small regions of origin Community brings out the social relations and politics that are played out in a circuit onginating in a particular locality The phrase "transnational community" does not assume a lack of conflict, stratification, or divisiveness (see Goldnng 1996b) Rather, it refers to a socially constructed form of organization that has empinical relevance for people from specific localities, at least in the Mexican case Transnational communities should not be assumed to develop in all migrant circuits, other forms of transnational social organization may occur, instead of or in addition to locality- or region-based transnational identities and communities Factors such as the size and position of the sending country within a hierarchy of nation-states, the spatial distribution of "sending" areas in particular countries, the magnitude and history of migration, patterns of labor market incorporation, geographic distribution of settlement, the prevalence of rural versus urban migration, and state policies in "sending" and "receiving" countries that affect transmigrants will lead to variation in forms of transnational collectivities Although it might be expedient to agree on a standard set of terms in the literature on transnationalism, existing variation calls for context-specific clanty and comparative research

13 There is a well developed hterature on immigrant politics, both histoncal and contemporary, to which I cannot do justice See, for example, Jacobson's (1995) work on Irısh, Polish, and East European Jewish migrants and the SpanishCuban-American and Philıppine-American wars, the review by Portes and Rumbaut (1990), and Glıck Schlller's (1999) chapter on states, transnational migration and nation-building

14 Nelson (1998) uses the term "political authorities" to refer to the vanous levels of "the state" that Cheranenses engage through their citizenship practices and 
discourse. This is a useful way of disaggregating the state and recognizing the multi-tiered quality of citizenship practices.

15. For example, undocumented persons and green-card holders may lack de jure citizenship, but be able to exercise some dimensions of citizenship substantively or de facto, e.g. if certain social citizenship benefits are provided because agency staff have a local policy of not requiring documentation. Formal citizens who do not practice citizenship (political or otherwise), could be seen as failing to exercise substantive citizenship.

16. I used (im)migrants in my dissertation (Goldring 1992), before finding the term "transmigrant" and the literature on transnationalism (e.g. Bash, Glick-Schiller and Szanton-Blanc 1994; Glick-Schiller et al. 1992). While I generally use transmigrant, it is sometimes useful to draw attention to the multiple embeddedness and ambiguity regarding future plans that even a term like transmigrant is supposed to address. Immigrants (people who move with the intention of settling) may become transmigrants, and transmigrants may become immigrants (cf. Glick Schiller 1999).

17. I am following Marshall's use of social citizenship to describe rights and entitlements such as education, public health, and social services provided by states and designed to help mitigate the effects of social inequality and capitalism.

18. Mexican and U.S. government officials and various development organizations are interested in promoting the investment of migrant remittances in productive infrastructure and employment generating activities, presumably as a way to reduce the "need" for migration. That private banks and credit unions are also interested, speaks to the financial gains to be made from remittance transfers. This topic is beyond the scope of this paper, but it is worth noting that there is a difference between individuals sending remittances, collective community projects, and individual or group profit-oriented investments (Goldring 1999b). An important element of success in community projects is that they not be seen as being for personal gain. Productive infrastructure is more commonly for an individual or family's gain. In addition to needing appropriate economic conditions, which do not obtain in many sending communities, investment in productive infrastructure is more likely to work when there is a very direct relationship between investors and beneficiaries.

19. For background on Mexican hometown organizations, see González Gutiérrez (1995), Imaz (1995), Zabin and Escala Rabadan (1998), Goldring (1992, 1996b, 1998b, 1999a), Smith (1995, 1997, 1998), Rivera (1998), Moctezuma (1998), FCZSC (1998), and Espinosa (1999).

20. See Goldring (1998b) on the role of transmigrants in the most recent gubernatorial race in Zacatecas. During the last municipal elections in Oaxaca, the Frente Indigena Oaxaqueño Binacional, one of the more explicitly political indigenous transmigrant organizations, working in conjunction with the PRD, won a local deputy and mayoral seat in Oaxaca (Bermejillo 1999; cf. Rivera-Salgado 1998).

21. Growing anti-immigrant hysteria and legislation in the United States, particularly in California, would later add to the rationale for increasing the profile of Mexican Consuls and Consulates and for the new policy of encouraging naturalization as a way for Mexicans to defend their rights in the United States (Martínez Saldaña 1998a; Guarnizo 1998; Interviews).

22. For more on the PCME, see Goldring (1997, 1998a, 1998b, 1999a), González Gutiérrez $(1993,1995)$, Guamizo (1998) and Smith $(1995,1997,1998)$. 
23 In theory, eyldatartos ran the risk of losing property nghts through prolonged absence At the same time, US earnings allowed migrants to buy ejudo and/or private property

24 Women from urban areas with histories of grassroots activism would be an exception to this generalization I do not wish to imply that mestizo women from rural areas are not interested in politics, or have no expenence in local organizations or politics I also want to guard against an essentializing tone with respect to "political culture " Rather, I am referring to an overall "chilly climate" for women in politics in Mexico, one shaped by the common sense that women do not belong in the public realm of la politica

25 A woman from Michoacan headed the Federation for one term (1983-85), before the Federation began working with the government in the matching funds program This was during a period when the Federation was not exclusively Zacatecan, but included clubs from other provinces

26 Most of my fieldwork took place during the governorship of Arturo Romo The subsequent change in government brought about important changes for the Federation (Goldring 1998b, 1999a) and meant delays in project implementation for 1998-99

\section{REFERENCES}

Basch, Linda, Nina Glıck-Schiller and Cristına Szanton Blanc

1994 Nations Unbound Transnational Projects, Postcolonial Predicaments, and Deterritonialized Nation-States Amsterdam Gordon and Breach

Becerril, Andrea

1999 Atribuyen al "temor" del PRI la cancelación de la reforma electoral La Jornada, July 2

Bennett, Vivienne

1998 Everyday Struggles Women in Urban Popular Movements and Territorially Based Protests in Mexico In Women's Participation in Mexican Political Life Victoria E Rodniguez, ed pp 116-130 Boulder Westview Press

Bermejlllo, Eugenio

1999 Amenazas de Ahogado La Jornada, February 17

Brubaker, Willam Rogers

1990 Immigration, Citzenship, and the Nation-State in France and Germany A Comparative Historical Analysis International Sociology 5(4) 379-407

Calderon Chelius, Letrcia

1998 El ABC del voto en el extenor L'Ordinarre Latıno-Americain 173-174 145-152 Camp, Roderic Al

1998 Women and Men, Men and Women Gender Patterns in Mexican Politics In Women's Participation in Mexican Political Life Victoria E Rodriguez, ed pp 167-178 Boulder Westview Press

Castañeda Gomez del Campo, Alejandra

1998 Transnational Politics Political Culture and Mexican Migration to the United States Dissertation Proposal University of California-Santa Cruz

Delgado, Hector

1993 New Immırants, Old unıons Organizing Undocumented Workers in Los Angeles Philadelphia Temple University Press 
Delgado Wise, Raúl

1991 Para entender a Zacatecas. In Biblioteca de las Entidades Federativas. Zacatecas: Sociedad, Economía, Política, Cultura. Mexico, D.F.: CIIH/UNAM.

Espinosa, Victor $M$.

1998 El dilema del retorno: migración, género y pertenencia en un contexto transacional. Zamora, Mexico: Colegio de Michoacán and Zapopan, Mexico: Colegio de Jalisco.

1999 La Federación de Clubes Michoacanos en Illinois: Historia y Perspectivas a Futuro de una Organización Civil Mexicana en Estados Unidos. Report of the Chicago-Michoacán Project. Chicago: Heartland Alliance for Human Needs and Human Rights.

Federación de Clubes Zacatecanos del Sur de California (FCZSC)

1998 Señorita Zacatecas. Annual Magazine. Norwalk, Ca.: FCZSC.

Garza, Adolfo

1999 Mexico Rejects Voting Abroad Plan. Associated Press Website, July 1.

Glick Schiller, Nina

1999 Transmigrants and Nation-States: Something Old and Something New in the U.S. Immigrant Experience. In The Handbook of International Migration: The American Experience. Charles Hirschman, Josh DeWind, and Philip Kasinitz, eds. pp. 94-119. New York: Russell Sage Foundation.

Glick-Schiller, Nina, Linda Basch and Cristina Blanc-Szanton, eds.

1994 Towards a Transnational Perspective on Migration: Race, Class, Ethnicity and Nationalism Reconsidered. New York: The New York Academy of Sciences.

Goldring, Luin

1992 La migración México-EUA y la transnationalización del espacio político y social: perspectivas desde el México Rural. Estudios Sociológicos X(29): $315-340$.

1996a Gendered Memory: Reconstructions of the Village by Mexican Transnational Migrants. In Creating the Countryside: The Politics of Rural and Environmental Discourse. Melanie DuPuis and Peter Vandergeest, eds. pp. 303-329. Temple University Press.

$1996 \mathrm{~b}$ Blurring Borders: Constructing Transnational Community in the Process of Mexico-U.S. Migration. Research in Community Sociology 6:69-104.

1997 The Mexican State and Transmigrant Organizations: Reconfiguring the Nation, Citizenship and State-Society Relations? Presented at the XX International Congress of the Latin American Studies Association. Guadalajara, Mexico, April 17-19.

1998a The Power of Status in Transnational Social Spaces. Comparative Urban and Community Research 6: 165-195.

1998b From Market Membership to Transnational Citizenship?: The Changing Politization of Transnational Spaces. L'Ordinaire Latino-Americain (Toulouse, France) 173-174 (Juillet-Déc.): 167-172.

1999a The Mexican State and Transmigrant Organizations: Negotiating the Boundaries of Membership and Participation in the Mexican Nation. Manuscript.

1999b Desarrollo, migradólares y la participación "ciudadana" de los norteños en Zacatecas. In Impacto de la Migración y las Remesas en el Crecimiento Económico Regional. Miguel Moctezuma and Héctor Rodríguez Ramírez, eds. pp. 77-87. México, D.F.: Senado de la República. 
1999c El Estado mexicano y las organizaciones transmigrantes: Reconfigurando la nación y las relaciones entre estado y sociedad civil? In Fronteras Fragmentadas. Gail Mummert, ed. pp. 297-316. Zamora: El Colegio de Michoacán.

González Gutiérrez, Carlos

1993 The Mexican Diaspora in California: The Limits and Possibilities of the Mexican Government. In The California-Mexico Connection. Abraham Lowenthal and Katrina Burgess, eds. pp. 221-235. Stanford: Stanford University Press.

1995 La organización de los inmigrantes mexicanos en Los Angeles: la lealtad de los oriundos. Revista Mexicana de Política Exterior 46: 59-101.

Grasmuck, Sherri and Patricia Pessar

1991 Between Two Islands: Dominican International Migration. Berkeley: University of California Press.

Guarnizo, Luis Eduardo

1998 The Rise of Transnational Social Formations: Mexican and Dominican State Responses to Transnational Migration. Political Power and Social Theory 12: 5-94.

Guarnizo, Luis Eduardo and Michael Peter Smith

1998 The Locations of Transnationalism. Comparative Urban and Community Research 6: 3-34.

' Hardy-Fanta, Carol

1993 Latina Politics, Latino Politics: Gender, Culture and Political Participation in Boston. Philadelphia: Temple University Press.

Hirsch, Jennifer

1999 Hay que saber lo que tienes en la casa: Notes Toward a Transnational Political Economy of Masculinity. Presented at the conference on Engendering Theories of Transnational Migration. Yale University, February 5-6.

Hondagneu-Sotelo, Pierrette

1994 Gendered Transitions: Mexican Experiences of Immigration. Berkeley: University of California Press.

Hondagneu-Sotelo, Pierrette and Ernestine Avila

1997 "I'm Here, but I'm There" The Meanings of Latina Transnational Motherhood. Gender and Society 11(5): 548-571.

\lrcorner Hondagneu-Sotelo, Pierrette and Michael A. Messner

' 1994 Gender Displays and Men's Power: The "New Man" and Mexican Immigrant Man. In Theorizing Masculinities. Harry Brod and Michael Kaufman, eds. pp. 200-218. Sage Publications.

Hondagneu-Sotelo, Pierrette and Cristina Riegos

1997 Sin organización no hay solución: Latina Domestic Workers and Non-traditional Labor Organizing. Latino Studies Journal 8(3): 54-81.

Imaz, Cecilia

1995 Las Organizaciones por Lugar de Origen de los Mexicanos en Estados Unidos (California, Illinois Y Nueva York). Presented at the XX Congreso de la Asociación Latinoamericana de Sociología. Mexico City, October 1-5.

INEGI

1996 Anuario Estadístico del Estado de Zacatecas. Aguascalientes: Instituto Nacional de Estadística, Geografía e Informática.

Infosel

2000 Mandan paisanos $8 \mathrm{Mil} \mathrm{MDD} \mathrm{al} \mathrm{año.} \mathrm{http://www.infosel.com/noticias/}$ nota $20000320 / 097162 . h$ tm $(3 / 20 / 00)$. 
Jacobson, Matthew Frye

1995 Special Sorrows: The Diasporic Imagination of Irish, Polish, and Jewish Immigrants in the United States. Cambridge, Mass: Harvard University Press.

Jones-Correa, Michael

1998 Between two Nations: The Political Predicament of Latinos in New York City. Ithaca: Cornell University Press.

Kanaiaupuni, Shawn

1993 Household Organization Strategies: the Migration and Work Activities of Women and Men in Mexican Families. Presented at the Binational Conference on Mexico-U.S. Migration. University of Chicago, October 7-9.

\section{Kandiyoti, Denise}

1988 Bargaining with Patriarchy. Gender \& Society 2: 274-490.

Levitt, Peggy

1997 Transnationalizing Community Development: The Case of Migration Between Boston and the Dominican Republic. Nonprofit and Voluntary Sector Quarterly 26(4): 509-526.

1999 Gender and Transnational Organization. Presented at the Conference on Engendering Theories of Transnational Migration. Yale University, February 5-6.

Lister, Ruth

1997 Citizenship: Towards a Feminist Synthesis. Feminist Review 57: $28-48$.

Mahler, Sarah J.

1996 Bringing Gender to a Transnational Focus: Theoretical and Empirical Ideas. Unpublished manuscript, Department of Anthropology, University of Vermont.

1998 Theoretical and Empirical Contributions Toward a Research Agenda for Transnationalism. Comparative Urban and Community Research 6: 64-100.

1999 Engendering Transnational Migration: A Case Study of Salvadorans. American Behavioral Scientist 42(4): 690-719.

Malkin, Victoria

1998 Migration, Modernity and Respect. In The Family and Gender in Transmigrant Circuits: A Case Study of Migration Between Western Mexico and New Rochelle, New York. Ph.D Dissertation, University College of London, Department of Social Anthropology, December.

Marshall, T. H.

1950 Citizenship and Social Class. Cambridge: Cambridge University Press.

Martínez Saldaña, Jesus

1998a Las Instituciones para la Democracia en México: Su Fracaso Ante la Emigración. Unpublished manuscript.

1998b In Search of Our Lost Citizenship: Mexican Immigrants, the Right to Vote, and the Transition to Democracy in Mexico. L'Ordinaire Latino-Americain 173-174: 153-162.

Massey, Douglas, Rafael Alarcón, Jorge Durand and Humberto González

1987 Return to Aztlán: The Social Process Of International Migration from Western Mexico. Berkeley: University of California Press.

Massey, Douglas, Luin Goldring and Jorge Durand

1994 Continuities in Transnational Migration: An Analysis of Nineteen Mexican Communities. American Journal of Sociology 99(6): 1492-1533. 
Massolo, Alejandra

1998 Women in the Local Arena and Municipal Power. In Women's Participation in Mexican Political Life. Victoria E. Rodríguez, ed. pp. 193-203. Boulder: Westview Press.

Mines, Richard

1981 Developing a Community Tradition of Migration: A Field Study in Rural Zacatecas, Mexico, and California Settlement Areas. Monographs in U.S.Mexican Studies No.3. La Jolla: Program in U.S.-Mexican Studies, U.C.-San Diego.

Moctezuma, Miguel

1998 Redes Sociales, Comunidades y Familias de Migrantes. Sain Alto, Zac, en Oakland, Ca. Ph.D Dissertation (Draft). Tijuana: El Colegio de la Frontera Norte.

Mummert, Gail

1988 Mujeres de migrantes y mujeres migrantes de Michoacán: Nuevos papeles para las que se quedan y para las que se van. In Movimientos de Población en el occidente de México. Tomás Calvo and Gustavo López, eds. pp. 281295. Mexico, D.F.: El Colegio de México.

Nagengast, Carole and Michael Kearney

1990 Mixtec ethnicity: Social identity, political consciousness, and political activism. Latin American Research Review 25(2): 61-91.

Nelson, Lise

1998 Las que defienden el pueblo: Emerging discourses and practices of citizenship in Cherán, Michoacán. Presented at the 1998 meeting of the Latin American Studies Association, Chicago, September 24-26.

Ong, Aiwah

1993 On the Edge of Empires: Flexible Citizenship among Chinese in Diaspora. Positions 1(3): 745-778.

1999 Flexible Citizenship: the Cultural Logics of Transnationality. Durham, N.C.: Duke University Press.

Padilla, Juan Manuel

1998 La Población de Zacatecas. Zacatecas: Facultad de Economía, Universidad Autónoma de Zacatecas.

Painter, Joe and Chris Philo

1995 Spaces of Citizenship: an Introduction. Political Geography 14(2): 107-120.

Pardo, Mary

1999 Gendered Citizenship: Mexican American Women and Grassroots Activism in East Los Angeles, 1986-1992. In Chicano Politics and Society in the Late Twentieth Century. David Montejano, ed. pp. 58-79. Austin: University of Texas Press.

Pessar, Patricia

1999a Situating Gender within a Transnational Social Field: Guatemalan Refugees and Returnees. Presented at the conference on Engendering Theories of Transnational Migration. Yale University, February 5-6.

$1999 \mathrm{~b}$ Engendering Migration Studies. American Behavioral Scientist 42(4): $577-600$.

Poder Ejecutivo Federal (PEF)

1995 Plan Nacional de Desarrollo, 1995-2000. Diario Oficial de la Federación (31 de mayo). Mexico, D.F.: Secretaría de Hacienda y Crédito Público. 
Portes, Alejandro, Lurs Guarmzo and Patricia Landolt

1999 The Study of Transnationalism Pitfalls and Promise of an Emergent Research Field Ethnic and Racral Studies 22(2) 217-237

Portes, Alejandro and Ruben Rumbaut

1990 Immigrant America A Portrait Berkeley University of California

Pries, Ludger (ed)

2001 New Transnational Social Spaces International Migration and Transnational Companes in the Early Twenty-first Century London and New York Routledge

Prokhovnk, Raia

1998 Public and Private Citzzenship Feminust Review 60 84-104

Reuters

1999 México PRI boicotea debate de reforma electoral en el Senado Reuters website, July 2

Rivera Salgado, Gaspar

1997 Movimientos Sociales Transfronterizos Reporte Evaluatıvo Comisionado por la Fundación Oxfam-Aménca Manuscript

1998 Radiografia de Oaxacahforna Masıosare, La Jornada, August 9

Rodríguez, Victona

1998 The Emerging Role of Women in Mexican Political Life In Women's Participation in Mexican Political Life Victoria E Rodríguez, ed pp 1-20 Boulder Westview Press

Ross Pineda, Raúl

1998 El voto incómodo Masiosare La Jornada, Sept 13

Rouse, Roger

1990 Men in Space Power and the Appropriation of Urban Form among Mexican Migrants in the United States Manuscript, Department of Anthropology, University of Michigan

1991 Mexican Migration and the Social Space of Postmodernusm Diaspora 1(1) 8-23

Salazar Rodriguez, Maria Martına

1996 Panorama de las Remesas por Migración Internacional en Zacatecas Masters Thesis, Political Science, UAZ, Zacatecas

Schuld, Veronica

1998 Market Citzzenship and the "New Democracies" The Ambrguous Legacies of Contemporary Chilean Women's Movements Soctal Politıcs 5(2) 232-249

Shafir, Gershon, ed

1998 The Citızenship Debates Minneapolıs University of Minnesota Press

Smith, Robert C

1995 Los Ausentes Siempre Presentes The Imagining, Making and Politics of a Transnational Community between New York and Ticuan, Puebla Ph D Dissertation, Department of Political Science Columbia University

1997 Reflections on Migration, the State and the Construction, Durability and Newness of Transnational Life Sozialen Welt 12

1998 Transnational Localities Community, Technology and the Politics of Membershup within the Context of Mexico and US Migration Comparative Urban and Community Research 6 196-238

1999 The Transnational Practice of Migrant Politics and Membership An Analysis of the Mexican Case with some Comparative and Practical Reflections In Impacto de la Migración y las Remesas en el Crecimiento Económico 
Regional. Hector Rodríguez and Miguel Moctezuma, eds. Mexico, D.F.: Senado de la República.

Stasiulis, Daiva and Abigail B. Bakan

1997 Negotiating Citizenship: The case of foreign domestic workers in Canada. Feminist Review 57: 112-139.

Stephen, Lynn

1998 Gender and Grassroots Organizing: Lessons from Chiapas. In Women's Participation in Mexican Political Life. Victoria E. Rodríguez, ed. pp. 146-163. Boulder: Westview Press.

Tarrés, Maria Luisa

1998 The Role of Women's Nongovernmental Organizations in Mexico. In Women's Participation in Mexican Political Life. Victoria E. Rodríguez, ed. pp. 131-145. Boulder: Westview Press.

World Bank

1994 Second Decentralization and Regional Development Project. Staff Appraisal Report, Mexico, August 19. Report No. 13032-ME.

Yuval-Davis, Nira

1997 Women, Citizenship and Difference. Feminist Review 57: 4-27.

Yuval-Davis, Nira and Floya Anthias, eds.

1989 Women, Nation, State. London: MacMillan Press.

Zabin, Carol and Luis Escala Rabadán

1998 Mexican Hometown Associations and Mexican Immigrant Political Empowerment in Los Angeles. The Aspen Institute Working Paper Series. Washington, D.C.: Aspen Institute. 